DOI https://doi.org/10.30525/978-9934-26-073-5-2-75

\title{
THE UNDERLYING PRINCIPLES OF THE CULTUROLOGICAL APPROACH TO TEACHING FOREIGN LANGUAGES
}

\author{
Tatarin V. P. \\ MA student, \\ Berdyansk State Pedagogical University \\ Berdyansk, Zaporizhzhia region, Ukraine
}

New demands caused by open borders and growing cross-cultural contacts among different language communities have modified the objectives of learning a foreign language (FL). Communicative competence is no longer the only important thing, since it often pushes students away from the cultural code of the target language. In practice, the communicative approach is being distorted, and communicative exercises are performed incorrectly. The traditional dominance of the linguistic component in the FL lessons leads, firstly, to the distortion of personal goals of mastering a FL and, secondly, to the trivialization of socio-cultural facts about the life of the country which language is being studied.

The issue was studied by many a scientist. In particular, I. Miazova studied the peculiarities of intercultural communication; A. Liddicoat, L. Papademetre, A. Scarino and M. Kohler studied the features of intercultural learning of a foreign language; S. Radul studied the milestones and issues of the formation of the intercultural competence; L. Sercu studied the peculiarities of teaching foreign languages in the intercultural world.

Using the linguistic and cultural experience acquired from a native language, as well as national-cultural behavior patterns, the inexperienced subject of intercultural communication mainly reduces the importance (or does not know at all) of FL norms, goals and functions of communication. Another problem is the inconsistency of a language studied from the school textbooks with the real one spoken by natives. These two reasons lead to communication gaps.

Currently, a typical situation after graduation is the inability to build productive communication, lack of speaking skills, and an underdeveloped sense of the cultural code. However, a foreign culture is that part of the general culture of mankind, which a student can master in the process of learning in social, psychological, pedagogical, and cognitive (cultural) aspects.

The culturological approach treats a student as a «linguistic personality», who has the following features: national consciousness, values, and ethic 276 
culture in general. Its task is to expand the general, social, and cultural horizons of students, stimulating their cognitive and intellectual processes.

It is worth noting that the expanding of knowledge about the culture also helps to receive acculturation, which is characterized as uncomfortable, one that requires a review of beliefs, values, attitudes and identity. However, the main point is not in raising students from the stance of another country, but the ability to compare cultural experience of another people with their own.

The aim of the culturological approach is to gain intercultural communicative competence (ICC). It includes: «willingness to engage with the foreign culture, self-awareness and the ability to look upon oneself from the outside, the ability to see the world through the others' eyes, the ability to cope with uncertainty, the ability to act as a cultural mediator, the ability to evaluate others' points of view, the ability to consciously use culture learning skills and to read the cultural context, and the understanding that individuals cannot be reduced to their collective identities» [3, p. 2].

The criterion for assessing the level of the ICC lies in the understanding of the culture of native speakers, knowledge of the similarities and differences between the target and source cultures, and, of course, the level of mastery in a FL. In this context, culture is seen as a common space, a product of human mind and activity, experience and norms that govern life, people's attitudes to new ideas, worldviews and social forms. Therefore, the purpose of schooling is the development of students who realize the special importance of preserving their own cultural identity and, at the same time, enriching it through initiation into a foreign culture.

Achieving the ICC through a culturological approach is subject to appropriate principles. In particular, scientists A. Liddicoat, L. Papademetre, A. Scarino and M. Kohler talk about the principle of active construction, the principle of making connections, the principle of social interaction, the principle of reflection, and the principle of responsibility [2].

The principle of active constructions means that a student must independently develop culturological knowledge as a part of their own identity through active involvement in the target culture (interaction with others, correspondence, use of modern technologies, etc.). It involves acquiring skills at noticing differences, reflecting on their nature and impact, and developing their own ways for addressing intercultural issues related to conditioned human behavior. According to this principle, the role of a teacher is not to give ready-made cultural information, but rather to stimulate curiosity, observation, discovery, discussion and experimentation, as well as selection and development of tasks that stimulate student's interest in expanding information about language and culture.

The principle of making connections aims to reinforce learning with prior knowledge and requires students to be challenged with an initial understanding 
of a foreign culture so that they can compare languages and cultures and fill the gap between native and target cultures. To implement this principle in FL lessons, a teacher should develop students' critical thinking and metacognitive skills.

The principle of social interaction implies that learning about culture is possible only through communication with others, because it gives students the opportunity to see the difference between cultures, share experiences, discuss and test the developed communication strategies in practice. The role of a teacher is to promote social participation, support the mental activity of students and improve the speech situation. In addition, this principle gives priority to socio-cultural interaction as the ultimate goal of FL education.

The principle of reflection means that the learning process must include reviewing and analyzing one's own experience. Students should monitor their results and be sure to discuss them, developing a metalanguage. The teacher's role focuses on setting goals for subsequent lessons, proving constructive criticism, and stimulating intercultural sensitivity.

The principle of responsibility assumes that the success of mastering the ICC depends on the willingness of students to learn and take responsibility for the development of their own cross-cultural qualities. At the same time, the motivational sphere plays an important role, as well as its elements, such as the image and competence of a teacher.

The implementation of the above-mentioned principles allows students to learn a FL in connection with culture. Active and interactive teaching methods stand as a helping hand for teachers who are willing to create a space for language-culture learning. The culturological approach is able to meet the educational needs of the XXI century and takes a prominent place among other approaches.

\section{References:}

1. Language, thought and reality. Selected writings of Benjamin Lee Whorf / edited by John B. Carroll. Cambridge, Massachusetts: Massachusetts Institute of Technology, 1956. $278 \mathrm{p}$.

2. Liddicoat, Anthony \& Papademetre, L \& Scarino, Angela \& Kohler, Michelle. (2003). Report on intercultural language learning. Report to the Australian Government Department for Education Science and Training (DEST). URL: https://www.researchgate.net/publication/276060725_Report_ on_intercultural_language_learning_Report_to_the_Australian_Government_ Department_for_Education_Science_and_Training_DEST.

3. Sercu L. FL teachers and intercultural competence: an international investigation. Clevedon: Multilingual Matters, 2005. 232 p. 